BENTHAM OPEN
CrossMark
Content list available at: www.benthamopen.com/TOBIOTJ/
DOI: $10.2174 / 1874070701812010033$

RESEARCH ARTICLE

\title{
Protease-, Pectinase- and Amylase- Producing Bacteria from a Kenyan Soda Lake
}

\author{
Kevin Raymond Oluoch ${ }^{1,2, *}$, Patrick Wafula Okanya ${ }^{2}$, Rajni Hatti-Kaul ${ }^{1}$, Bo Mattiasson ${ }^{1}$ and Francis \\ Jakim Mulaa ${ }^{2}$ \\ ${ }^{I}$ Department of Biotechnology, Center for Chemistry and Chemical Engineering, Lund University, Lund, Sweden \\ ${ }^{2}$ Department of Biochemistry, University of Nairobi, Nairobi, Kenya
}

Received: February 2, 2018

Revised: March 3, 2018

Accepted: March 28, 2018

\section{Abstract:}

\section{Background:}

Alkaline enzymes are stable biocatalysts with potential applications in industrial technologies that offer high quality products.

\section{Objective:}

The growing demand for alkaline enzymes in industry has enhanced the search for microorganisms that produce these enzymes.

\section{Methods:}

Eighteen bacterial isolates from Lake Bogoria, Kenya, were screened for alkaline proteases, pectinases and amylases; characterized and subjected to quantitative analysis of the enzymes they produced.

\section{Results:}

The screening analysis ranked 14, 16 and 18 of the bacterial isolates as potent producers of alkaline proteases, pectinases and amylases, respectively. The isolates were classified into two groups: Group 1 (16 isolates) were facultatively alkaliphilic $B$. halodurans while group 2 ( 2 isolates) were obligately alkaliphilic B. pseudofirmus. Further analysis revealed that group 1 isolates were divided into two sub-groups, with sub-group I (4 isolates) being a phenotypic variant sub-population of sub-group II (12 isolates). Variation between the two populations was also observed in their enzymatic production profiles e.g. sub-group I isolates did not produce alkaline proteolytic enzymes while those in sub-group II did so $(0.01-0.36 \mathrm{U} / \mathrm{ml})$. Furthermore, they produced higher levels of the alkaline pectinolytic enzyme polygalacturonase $(0.12-0.46 \mathrm{U} / \mathrm{ml})$ compared to sub-group II isolates $(0.05-0.10 \mathrm{U} / \mathrm{ml})$, which also produced another pectinolytic enzyme - pectate lyase $(0.01 \mathrm{U} / \mathrm{ml})$. No clear distinction was however, observed in the production profiles of alkaline amylolytic enzymes by the isolates in the two sub-populations [0.20-0.40 U/ml (amylases), 0.24-0.68 $\mathrm{U} / \mathrm{ml}$ (pullulanases) and $0.01-0.03 \mathrm{U} / \mathrm{ml}$ (cyclodextrin glycosyl transferases)]. On the other hand, group 2 isolates were phenotypically identical to one another and also produced similar amounts of proteolytic $(0.38,0.40 \mathrm{U} / \mathrm{ml})$ and amylolytic [amylases $(0.06,0.1 \mathrm{U} / \mathrm{ml})$, pullulanases $(0.06,0.09 \mathrm{U} / \mathrm{ml})$ and cyclodextrin glycosyl transferases $(0.01,0.02 \mathrm{U} / \mathrm{ml})]$ enzymes.

\section{Conclusion:}

The facultatively alkaliphilic B. halodurans and obligately alkaliphilic B. pseudofirmus isolates are attractive biotechnological sources of industrially important alkaline enzymes.

Keywords: Soda lake, Alkaliphiles, Proteases, Pectinases, Amylases, Bacillus halodurans, Bacillus pseudofirmus.

\footnotetext{
* Address correspondence to this author at the Department of Biochemistry, University of Nairobi, Nairobi, Kenya; Tel: +254-727 110448; E-mail: kevin.oluoch@uonbi.ac.ke
} 


\section{INTRODUCTION}

Soda lakes are some of the main types of alkaline environments that occur naturally on earth. They are characterized by high alkalinity ( $\mathrm{pH} 8-12$ ), large amounts of $\mathrm{Na}_{2} \mathrm{CO}_{3}$ and $\mathrm{NaCl}$ [5\% (w/v) $\mathrm{NaCl}$ to saturation], and high and low concentrations of $\mathrm{Na}^{+}$and $\mathrm{Mg}^{2+} / \mathrm{Ca}^{2+}$ ions, respectively, due to evaporative concentration [1, 2]. Although soda lakes have a wide geographical distribution on earth, their hostile nature and inaccessibility have contributed to only a few of them being explored from the limnological and microbiological point of view. Among the most studied soda lakes are those fed by carbonated hot springs in the Kenyan Rift valley area. These alkaline water bodies also support a considerably diverse population of alkaliphiles i.e. microorganisms that are able to grow at optimal $\mathrm{pH}$ values $>9.0$, but fail to grow/grow slowly at around $\mathrm{pH} 7$ [3]. They include archea, Gram negative protobacteria (e.g. Pseudomonas, Halomonas and Deleya) and Gram positive bacteria/eubacteria (e.g. Bacillus and Clostridium) [4].

Alkaliphilic bacteria, especially those belonging to the genus Bacillus have generated a lot of interest because of their capability to thrive under harsh alkaline conditions and to produce alkali- stable enzymes [5]. The unique characteristics of these biocatalysts, therefore, present an opening for their utilization in industrial technologies that offer high quality products. For example, alkaline enzymes have been shown to have a great impact in laundry and dishwashing detergents [6]. Other areas of application of alkaline enzymes are in the leather, silver recovery, pharmaceutical, chemical, food and feed, pulp and paper, and textile industries as well as in wastewater treatment and cyclodextrin production [6 - 10].

A considerable number of bioprospection studies for bacteria have been carried out world-wide for production of alkaline enzymes, but only a few such studies have been forthcoming from Kenya. In this article, we report on the quantitative screening of bacteria isolated from different samples collected in Lake Bogoria (a Kenyan soda lake) hot spring wells for production of alkaline proteases, pectinases and amylases; characterization of the bacterial isolates and qualitative determination of the enzymes they produce.

\section{MATERIALS AND METHODS}

\subsection{Source of Microorganisms}

Soil, water, polymer and maize-cob samples were collected in sterile bottles from different sites within alkaline hot spring wells and their drainage channels leading to Lake Bogoria $\left(00^{\circ} 15^{\prime} \mathrm{N} \& 36^{\circ} 06^{\prime}\right.$ E), Kenya. Samples were transported to the Department of Biochemistry, University of Nairobi, Kenya, where they were stored at $-20{ }^{\circ} \mathrm{C}$ before use. Reference strains Bacillus halodurans DSM 497 and Bacillus pseudofirmus DSM 8715 were bought from Deutsche Sammlung von Mikroorganismen und Zellkulturen (DSMZ), Braunschweig, Germany. All chemicals were purchased from standard sources.

\subsection{Isolation}

One hundred and ninety soda lake bacterial isolates, designated as LBW, LBS or LBK, were isolated from the Lake Bogoria samples by serial dilution on modified Horikoshi I solid medium (pH 10) [11]. Eighteen isolates were chosen for this study based on their dominance in growth during the isolation process. Table 1 shows the origins of the chosen bacterial isolates and the physical characteristics recorded at the sampling sites.

Table 1. The origins of the soda lake bacterial isolates used in this study.

\begin{tabular}{|c|c|c|c|c|}
\hline Isolate & Sampling Site & Sample Type & pH & Temp $\left(^{\circ} \mathbf{C}\right)$ \\
\hline LBW 2719 & Hot spring well no. 2 & Soil & 9 & 65 \\
\hline LBW 226 & Hot spring well no. 2 & Polymer & 9 & 65 \\
\hline LBW 318 & Hot spring well no. 3 & Maize-cob & 9 & 63 \\
\hline LBS 77 & Water & 9 & 60 \\
\hline LBK 261 & Upstream drainage channel of hot spring well no. 7 & Water & 9 & 54 \\
\hline LBW 4512 & Periphery of hot spring well no. 2 & Polymer & 9 & 50 \\
\hline LBW 327 & Periphery of hot spring well no. 4 & Polymer & 9 & 57 \\
\hline LBW 434 & Periphery of hot spring well no. 3 & Polymer & 9 & 52 \\
\hline LBW 7526a & Periphery of hot spring well no. 4 & Polymer & 9.5 & 55 \\
\hline LBW 39 & Periphery of hot spring well no. 7 & Polymer & 9 & 58 \\
\hline LBW 7526b & Periphery of hot spring well no. 3 & Polymer & 9.5 & 56 \\
\hline
\end{tabular}


(Table 1) contd....

\begin{tabular}{|c|c|c|c|c|}
\hline Isolate & Sampling Site & Sample Type & $\mathbf{p H}$ & Temp $\left({ }^{\circ} \mathrm{C}\right)$ \\
\hline LBW 328 & Periphery of hot spring well no. 3 & Polymer & 9 & 57 \\
\hline LBS 16 & Downstream drainage channel of hot spring well no. 1 & Soil & 9 & 45 \\
\hline LBW 625 & Periphery of hot spring well no. 6 & Soil & 9 & 55 \\
\hline LBW 446 & Periphery of hot spring well no. 4 & Polymer & 9 & 50 \\
\hline LBW 5117 & Periphery of hot spring well no. 5 & Soil & 8 & 51 \\
\hline LBW 313 & Periphery of hot spring well no. 3 & Maize-cob & 9 & 50 \\
\hline LBW 317 & Periphery of hot spring well no. 3 & Maize-cob & 9 & 48 \\
\hline
\end{tabular}

\subsection{Screening}

The soda lake bacterial isolates were subjected to plate-test screening for production of alkaline proteases, pectinases and amylases, respectively. Screening for protease production was performed as described by Juwon and Emanuel [12]. The solid gelatin-nutrient agar medium [adjusted to $\mathrm{pH} 10.5$ with $20 \%(\mathrm{w} / \mathrm{v}) \mathrm{Na}_{2} \mathrm{CO}_{3}$ ] was spotinoculated with $1 \mu \mathrm{l}$ of each isolate and cultures incubated at $37^{\circ} \mathrm{C}$ for $72 \mathrm{~h}$. Complete degradation of gelatin by the isolates is manifested by the formation of halos around positive protease producing colonies after flooding the plate with an aqueous solution of saturated ammonium sulfate $\left(769 \mathrm{~g}^{-1}\right)$.

Screening for pectinase production was performed as described by Soares et al. [13]. The solid pectin medium was prepared according to Kelly and Fogarty [14] and its $\mathrm{pH}$ adjusted to 10.5 with $20 \%$ (w/v) $\mathrm{Na}_{2} \mathrm{CO}_{3}$. The medium was spot-inoculated with $1 \mu \mathrm{l}$ of each isolate and the plate incubated at $37^{\circ} \mathrm{C}$ for $72 \mathrm{~h}$. The assay plate was developed by staining with Lugol's iodine ( $5.0 \mathrm{~g}$ potassium iodide, $1.0 \mathrm{~g}$ iodine and $330 \mathrm{ml} \mathrm{H}_{2} \mathrm{O}$ ) dye solution and the presence of halos around the colonies used as an indication of pectinase producing isolates.

Amylase production by the isolates was evaluated by inoculating $1 \mu \mathrm{l}$ of each isolate on Horikoshi II solid medium [15] ( $\mathrm{pH} 10.5)$ and incubating at $37^{\circ} \mathrm{C}$ for $72 \mathrm{~h}$. The assay plate was flooded with Gram's iodine $(1.27 \mathrm{~g}$ iodine in $10 \mathrm{ml}$ distilled water containing $2 \mathrm{~g}$ potassium iodide, and diluted to $300 \mathrm{ml}$ with distilled water) dye solution and the presence of halos around the colonies used as an indication of amylase producing isolates [16].

The efficiency of the proteases, pectinases and amylases to solubilize gelatin, pectin and starch respectively, and thus form halos around the colonies during the screening processes above, was determined qualitatively in terms of solubilization index (SI) value for each isolate calculated using the formula: SI = mean Diameter of halo $(\mathrm{Dh})$ $(\mathrm{mm}) /$ mean Diameter of colony $(\mathrm{Dc})(\mathrm{mm})$ [17]. The obtained mean SI values were used to rank the isolates as excellent producers of the enzymes when the colonies presented halo sizes $>3.0$; very good producers when the halos were $2.0<\mathrm{SI} \leq 3.0$; good producers when halos were $1.0<\mathrm{SI} \leq 2.0$; weak producers when halos were $0<\mathrm{SI} \leq 1.0$ (or not clear); producers of minor and unquantifiable enzymes when halo sizes cannot be determined and poor producers when no halos were observed.

\subsection{Phenotypic and Molecular Characterization}

Identification of the soda lake bacterial isolates was performed on the basis of their phenotypic and molecular characterization after growing them on solid nutrient media (adjusted to $\mathrm{pH} 10.5$ with $20 \%$ (w/v) $\mathrm{Na}_{2} \mathrm{CO}_{3}$ ) at $37{ }^{\circ} \mathrm{C}$ for different periods of time as described below:

\subsubsection{Morpholgical, Biochemical and Physiological Characterization}

For cell shape determination and classification as Gram positive/Gram negative, 12 or $48 \mathrm{~h}$ old colonies were subjected to Gram's staining by the method described by Gerhardt et al. [18]. The $\mathrm{KOH}$ test was also done to corroborate the Gram stain results [19]. For the detection of spores, $72 \mathrm{~h}$ old colonies were treated with saline [0.9\% $(\mathrm{w} / \mathrm{v})$ ] solution on microscope slides and observed under a phase contrast microscope (Leica EZA D, Cambridge, UK). To study the colony morphology of the isolates, $48 \mathrm{~h}$ old cultures were evaluated with the naked eye.

Catalase test was performed by the method described by Gerhardt et al. [18] while oxidase test was carried out using oxidase reagent according to Gordon-McLeod (Sigma-Aldrich) on 12 or $48 \mathrm{~h}$ old colonies, as recommended by the manufacturer. Production of effervescence due to catalase-catalyzed breakdown of $\mathrm{H}_{2} \mathrm{O}_{2}$ to molecular $\mathrm{O}_{2}$ indicates a positive reaction while change in the color of bacterial colony to purple is a positive oxidase reaction.

The effects of $\mathrm{pH}(7.0-11.0)$ (alkaliphily test), temperature $\left(25-65{ }^{\circ} \mathrm{C}\right)$, and salinity $[0-18 \%(\mathrm{w} / \mathrm{v}) \mathrm{NaCl}]$ on growth of the isolates, as well as oxygen requirement- and cell motility- tests, were carried out according to Martins $e t$ 
al. [20] on $48 \mathrm{~h}$ old cultures.

\subsubsection{S rDNA Amplification, DNA Sequencing, Phylogenetic Analysis and Accession Numbers}

Genomic DNA was extracted from $24 \mathrm{~h}$ old soda lake bacterial colonies using PureLink® Genomic DNA extraction kit (Invitrogen Life Technologies ${ }^{\mathrm{TM}}$, CA, USA) as per the manufacturer's instructions and their A260/A280 and A260/A230 ratios checked to assess their purity [21]. 16S rDNAs were PCR amplified using universal forward 8-27F (5'-AGAGTTTGATCCTGGCTCAG-3') and reverse 1492R (5'-CTACGGCTACCTTGTTACGA-3') primers in a Gene Amp PCR system 9700 (Applied Biosystems, CA, USA [22]. Amplified 16S rDNA fragments were purified from a $1 \%(\mathrm{w} / \mathrm{v})$ agarose gel using a Qiagen DNA purification kit (Limburg, Netherlands) as recommended by the manufacturer and sequenced on both strands at Macrogen Europe Laboratory (Amsterdam, Netherlands). DNA Baser Sequence Assembler (version 4.20) was used to edit and assemble contigs from chromatograms. Assembled nucleotide sequences were aligned with those obtained in the GeneBank of NCBI in MUSCLE [23]. A Phylogenetic tree was then constructed from the aligned nucleotide sequences using the Bayesian phylogenetic method executed in MrBayes bioinformatics software version 3.1.2 [24] and visualised using Fig Tree software version 1.2.2 (http://tree.bio.ed.ac.uk/). The 16S rDNA sequences determined in this study have been deposited in the GenBank at NCBI database under accession numbers KU321024 to KU321040. The sequence of isolate LBK 261 whose accession number is AY423275 was also deposited in the GenBank.

\subsection{Production Media and Assay Procedure for Enzyme Activity Determination}

The soda lake bacterial isolates were inoculated separately in $50 \mathrm{ml}$ alkaline broth medium (in $250 \mathrm{ml}$ conical flasks) prepared as described in the screening section for amylases and pectinases above, but without agar. Each isolate was similarly inoculated in separate $50 \mathrm{ml}$ alkaline broth media (pH adjusted to $10.5 \mathrm{using} 20 \% \mathrm{Na}_{2} \mathrm{CO}_{3}$ ) containing 0.5 g chicken quill feathers and $300 \mu \mathrm{L}^{-1}$ trace elements $\left[\left(\mathrm{g} / \mathrm{L}^{-1}\right): \mathrm{MnCl}_{2} 4 \mathrm{H}_{2} \mathrm{O}(15.1), \mathrm{CuSO}_{4} 5 \mathrm{H}_{2} \mathrm{O}(0.125), \mathrm{Co}\left(\mathrm{NO}_{3}\right)_{2}\right.$ $6 \mathrm{H}_{2} \mathrm{O}(0.23), \mathrm{CaCl}_{2} 2 \mathrm{H}_{2} \mathrm{O}$ (1.7), $\mathrm{Na}_{2} \mathrm{MoO}_{4} 2 \mathrm{H}_{2} \mathrm{O}(0.125), \mathrm{H}_{3} \mathrm{BO}_{3}$ (2.5), $\mathrm{FeSO}_{4} 7 \mathrm{H}_{2} \mathrm{O}$ (1.3), $\mathrm{ZnSO}_{4} 7 \mathrm{H}_{2} \mathrm{O} 2.5 \mathrm{ml}$ of $18.3 \mathrm{M}$ $\mathrm{H}_{2} \mathrm{SO}_{4}$ ]. All cultures were cultivated at $37^{\circ} \mathrm{C}$ and $200 \mathrm{rpm}$ for $48 \mathrm{~h}$, after which they were centrifuged at $4,000 \mathrm{rpm}$ and $4{ }^{\circ} \mathrm{C}$ for $30 \mathrm{~min}$. Cell-free culture supernatants from the chicken quill-feather, pectin and starch media were used as crude sources for quantitative determination of protease, pectinase and amylase activities, respectively, in duplicates, as described below:

\subsubsection{Protease Activity Assay}

Protease activity determination was performed by the method described by Bakhtiar et al. [25], but with a slight modification. $0.5 \mathrm{ml}$ enzyme was added to $0.5 \mathrm{ml} 1 \%$ (w/v) casein in $50 \mathrm{mM}$ glycine-NaOH buffer $\mathrm{pH} 10.5$ and the mixture incubated at $50{ }^{\circ} \mathrm{C}$ for $20 \mathrm{~min}$. The reaction was stopped by adding $0.5 \mathrm{ml} 10 \%(\mathrm{w} / \mathrm{v})$ ice-cold trichloroacetic acid, left to stand for $5 \mathrm{~min}$ at $4{ }^{\circ} \mathrm{C}$ and centrifuged at $8,000 \mathrm{rpm}$ at the same temperature for $2 \mathrm{~min} .0 .5 \mathrm{ml}$ supernatant was obtained and $2.5 \mathrm{ml} 0.5 \mathrm{M}$ sodium carbonate and $0.5 \mathrm{ml}$ three-fold diluted Folin-Ciocalteau phenol reagent added to it in that order. The reaction mixture was left undisturbed at room temperature for $30 \mathrm{~min}$ and the absorbance read at $600 \mathrm{~nm}$. One unit of protease activity was defined as the amount of enzyme that liberated $1 \mu \mathrm{mol}$ of tyrosine per min under the standard assay conditions.

\subsubsection{Pectinase Activity Assay}

Polygalacturonase (PGase) activity determination was carried out by adding $0.2 \mathrm{ml}$ enzyme to $0.8 \mathrm{ml} 0.5 \%$ (w/v) polygalacturonic acid sodium salt in $50 \mathrm{mM}$ glycine- $\mathrm{NaOH}$ buffer $\mathrm{pH} 10.5$ and incubating the reaction mixture at $55^{\circ} \mathrm{C}$. After $10 \mathrm{~min}$ of incubation, the amount of reducing sugars formed was tracked down by a modified version of the DNS method [26]. One unit of PGase activity was defined as the amount of enzyme that liberated $1 \mu$ mol of reducing sugars as monogalacturonic acid per min under the standard assay conditions.

Pectate lyase (PecL) activity was determined by the method described by Soriano et al. [27], but with a slight modification. $0.1 \mathrm{ml}$ crude enzyme was added to $1.9 \mathrm{ml} 0.2 \%(\mathrm{w} / \mathrm{v})$ polygalacturonic acid sodium salt in $50 \mathrm{mM}$ glycine $\mathrm{NaOH}$ buffer $\mathrm{pH} 10.5$, which also contained $0.5 \mathrm{mM} \mathrm{CaCl}_{2}$. The assay mixture was incubated at $55^{\circ} \mathrm{C}$ for $2.5 \mathrm{~min}$ and increase in A $232 \mathrm{~nm}$ measured at intervals of 0.5 min after terminating the reaction with $2 \mathrm{ml} 50 \mathrm{mM} \mathrm{HCl}$ and centrifuging the tube at $14,000 \mathrm{rpm}(5 \mathrm{~min})$. One unit of PecL activity was defined as the amount of enzyme that liberated $1 \mu$ mole unsaturated galacturonates under the standard assay conditions. Molar extinction coefficient of the unsaturated product was assumed to be $4,600 \mathrm{M}^{-1} \mathrm{~cm}^{-1}$. 


\subsubsection{Amylase Activity Assay}

Amylase and pullulanase activity determination was performed as described by Martins et al. [20], but with some modification. $0.1 \mathrm{ml}$ crude enzyme was added to $0.4 \mathrm{ml} 0.3 \%$ (w/v) starch in $50 \mathrm{mM}$ glycine- $\mathrm{NaOH}$ buffer $\mathrm{pH} 10.5$ and $0.4 \mathrm{ml} 0.5 \%(\mathrm{w} / \mathrm{v})$ pullulan in $50 \mathrm{mM}$ glycine- $\mathrm{NaOH}$ buffer $\mathrm{pH} 10.5$, respectively. Reaction mixtures were incubated at $55{ }^{\circ} \mathrm{C}$ and after $10 \mathrm{~min}$, the amount of reducing sugars formed in both assays were tracked down by a modified version of the DNS method [26]. One unit of amylase (or pullulanase) activity was defined as the amount of enzyme that liberated $1 \mu \mathrm{mol}$ of reducing sugars per min under the standard assay conditions.

Cyclodextrin glycosyltransferase (CGTase) activity determination was performed as described by Martins et al. [20], but with slight modification. $0.1 \mathrm{ml}$ enzyme was mixed with $0.7 \mathrm{ml} 5 \%(\mathrm{w} / \mathrm{v})$ pre-incubated $\left(50{ }^{\circ} \mathrm{C}, 5 \mathrm{~min}\right)$ maltodextrin in $50 \mathrm{mM}$ glycine- $\mathrm{NaOH}$ buffer $\mathrm{pH} 10.5$. The reaction mixture was incubated at $50{ }^{\circ} \mathrm{C}$ and after $25 \mathrm{~min}$ the reaction was stopped by adding $375 \mu \mathrm{l} 0.15 \mathrm{M} \mathrm{NaOH}$. This was followed by a further addition of $0.1 \mathrm{ml} 0.02 \%$ (w/v) phenolphthalein in $5 \mathrm{mM} \mathrm{Na}_{2} \mathrm{CO}_{3}$, after which the reaction mixture was left to stand at room temperature for 15 min and the absorbance read at $550 \mathrm{~nm}$. One unit of CGTase activity was defined as the amount of enzyme that liberated $1 \mu \mathrm{mol}$ of $\beta$-cyclodextrin per min under the standard assay conditions.

\section{RESULT AND DISCUSSION}

Eighteen soda lake bacteria were isolated from different samples collected in hot spring wells and their drainage channels in L. Bogoria, Kenya, and screened qualitatively on solid gelatin, pectin and starch media ( $\mathrm{pH} 10.5)$ for production of alkaline proteases, pectinases and amylases, respectively. The screening data analysis showed that 14,16 and 18 isolates formed clear halos around their respective colonies on solid gelatin, pectin and starch media, respectively (Fig. 1), thus suggesting that all were potent producers of alkaline amylases, while the majority were producers of proteases and pectinases. The size of halos formed (SI) depended on the efficiencies of the enzymes produced by the isolates to solubilize the starch, gelatin and pectin in their respective media, resulting in the decolorization of the dye around the positive colonies on both the starch and pectin plates, and failure of the $\left(\mathrm{NH}_{4}\right)_{2} \mathrm{SO}_{4}$ solution to precipitate proteins around the positive colonies.

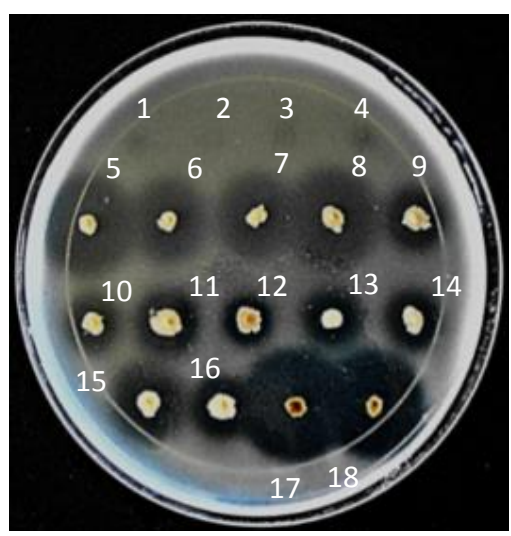

(a)

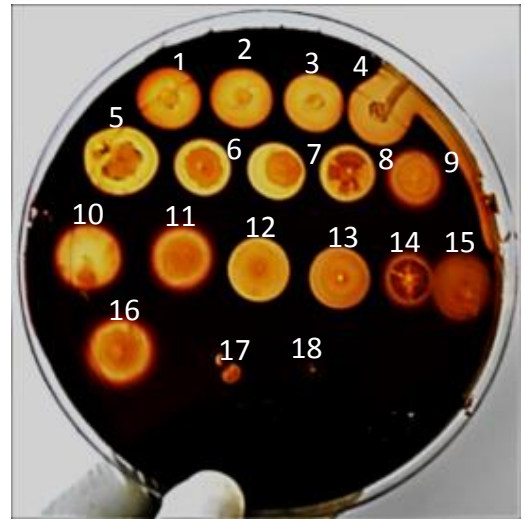

(b)

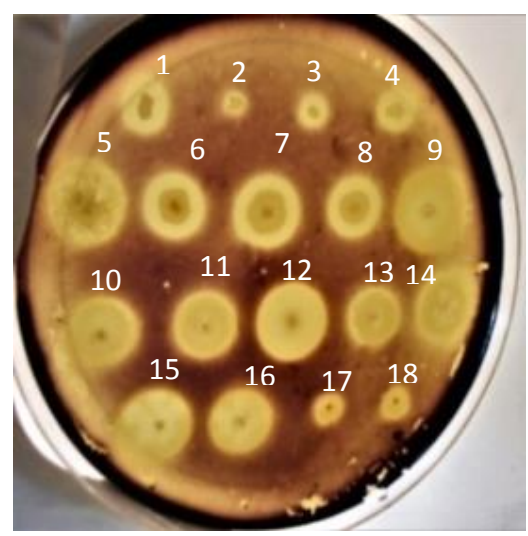

(c)

Fig. (1). Screening plate assays for alkaline protease, pectinase and amylase production by the soda lake bacterial isolates as seen on solid gelatin (a), pectin (b) and starch (c) media (pH 10.5), respectively. $1=$ LBW 2719, $2=$ LBW 226, $3=$ LBW 318, $4=$ LBS 77, 5 $=$ LBK 261, $6=\mathrm{LBW} 4512,7=\mathrm{LBW} 327,8=\mathrm{LBW} 434,9=\mathrm{LBW} 7526 \mathrm{a}, 10=\mathrm{LBW} 39,11=\mathrm{LBW} 7526 \mathrm{~b}, 12=\mathrm{LBW} 328,13=$ LBS 16, $14=$ LBW 625, $15=$ LBW 446, $16=$ LBW 5117, $17=$ LBW 313 and $18=$ LBW 317.

The diameter of the colonies (Dc) and that of their respective halos (Dh) were then measured (Table 2) and used to calculate the size of the halos or amount of enzymes (SI values) the isolates produced (Table 2 and Fig. 2). 


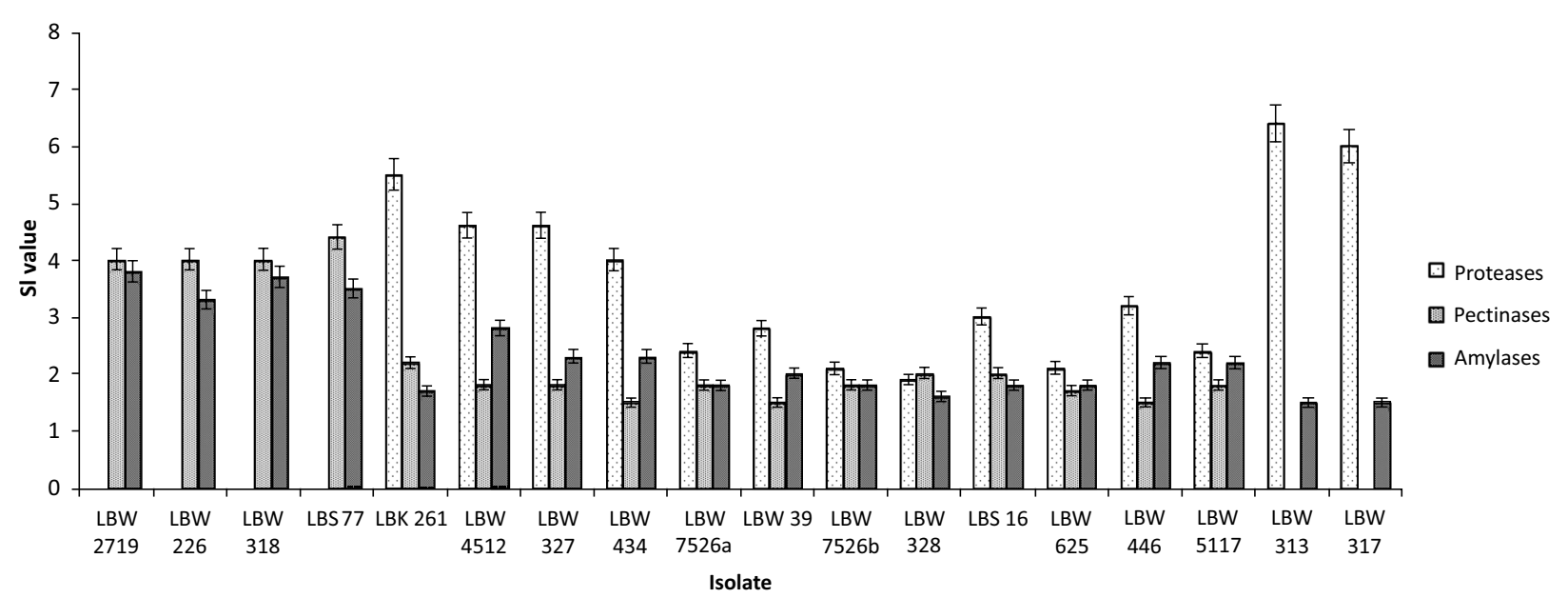

Fig. (2). Production of alkaline proteases, pectinases and amylases by the soda lake bacterial isolates following plate-test screening on gelatin, pectin and starch media $(\mathrm{pH} 10.5)$.

Table 2. SI values obtained for alkaline proteases, pectinases and amylases following plate-test screening.

\begin{tabular}{|c|c|c|c|c|c|c|c|c|c|}
\hline Isolate & \multicolumn{4}{|c|}{ Proteases } & \multicolumn{3}{|c|}{ Pectinases } & \multicolumn{3}{|c|}{ Amylases } \\
\hline Isolate & $\mathbf{D c}$ & $\mathbf{D h}$ & $\mathbf{S I}$ & $\mathbf{D c}$ & $\mathbf{D h}$ & $\mathbf{S I}$ & $\mathbf{D c}$ & Dh & SI \\
\hline Isolate & $\mathbf{( m m )}$ & $\mathbf{( m m )}$ & $\mathbf{( D h} / \mathbf{D c})$ & $\mathbf{( m m})$ & $\mathbf{( m m})$ & $\mathbf{( D h} / \mathbf{D c})$ & $\mathbf{( m m})$ & $\mathbf{( m m})$ & $\mathbf{( D h} / \mathbf{D c})$ \\
\hline LBW 2719 & $\mathrm{a}$ & 2 & $\mathrm{~b}$ & 5 & 20 & 4 & 4 & 15 & 3.8 \\
\hline LBW 226 & $\mathrm{a}$ & 2 & $\mathrm{~b}$ & 5 & 20 & 4 & 3 & 10 & 3.3 \\
\hline LBW 318 & $\mathrm{a}$ & 2 & $\mathrm{~b}$ & 5 & 20 & 4 & 3 & 11 & 3.7 \\
\hline LBS 77 & $\mathrm{a}$ & 2 & $\mathrm{~b}$ & 5 & 22 & 4.4 & 4 & 14 & 3.5 \\
\hline LBW 261 & 5 & 28 & 5.6 & 10 & 22 & 2.2 & 13 & 22 & 1.7 \\
\hline LBW 4512 & 5 & 23 & 4.6 & 10 & 18 & 1.8 & 8 & 22 & 2.8 \\
\hline LBW 327 & 5 & 23 & 4.6 & 10 & 18 & 1.8 & 9 & 21 & 2.3 \\
\hline LBW 434 & 7 & 28 & 4 & 12 & 18 & 1.5 & 8 & 18 & 2.3 \\
\hline LBW 7526a & 8 & 19 & 2.4 & 10 & 18 & 1.8 & 13 & 23 & 1.8 \\
\hline LBW 39 & 6 & 17 & 2.8 & 12 & 18 & 1.5 & 11 & 22 & 2 \\
\hline LBW 7526b & 8 & 17 & 2.1 & 10 & 18 & 1.8 & 11 & 20 & 1.8 \\
\hline LBW 328 & 8 & 15 & 1.9 & 10 & 20 & 2 & 14 & 23 & 1.6 \\
\hline LBS 16 & 5 & 15 & 3 & 10 & 20 & 2 & 11 & 20 & 1.8 \\
\hline LBW 625 & 7 & 15 & 2.1 & 10 & 17 & 1.7 & 11 & 20 & 1.8 \\
\hline LBW 446 & 6 & 19 & 3.2 & 15 & 22 & 1.5 & 13 & 28 & 2.2 \\
\hline LBW 5117 & 7 & 17 & 2.4 & 10 & 18 & 1.8 & 11 & 24 & 2.2 \\
\hline LBW 313 & 5 & 32 & 6.4 & 2 & No halo & c & 8 & 12 & 1.5 \\
\hline LBW 317 & 5 & 30 & 6 & 1 & No halo & c & 8 & 12 & 1.5 \\
\hline
\end{tabular}

Key:

a, No visible growth.

', Minor and unquantifiable enzyme.

', No enzyme produced.

Based on the calculated SI values, seven isolates (LBW 261, LBW 4512, LBW 327, LBW 434, LBW 446, LBW 313 and LBW 317) were ranked as excellent producers of proteases and four (LBW 2719, LBW 226, LBW 318 and LBS 77) as excellent producers of both pectinases and amylases (SI > 3.0) (Fig. 2). The rest of the isolates were either very good $(2.0<\mathrm{SI} \leq 3.0)$, good $(1.0<\mathrm{SI} \leq 2.0)$ or poor producers (no halos formed) of these enzymes. In addition, four isolates (LBW 2719, LBW 226, LBW 318 and LBS 77) were identified as producers of minor and unquantifiable proteases as they presented unclear halos due to poor (invisible) bacterial growths.

Based on their morphological and biochemical tests, all the soda lake bacterial isolates were motile, rod shaped, Gram positive, catalase- and oxidase- positive endospore-forming bacterial cells, implying that they belonged to the genus Bacillus [28]. The colonies of these bacilli isolates were predominantly white, transluscent, glistening, circular, flat, smooth and had entire margins (Table 3). 
Table 3. Colony morphological characteristics of the soda lake bacterial isolates.

\begin{tabular}{|c|c|c|}
\hline Isolate & Pigment & Shape, height, texture and margin \\
\hline LBW 2719 & White, opaque and dull & Circular, raised, rough and dry, entire \\
\hline LBW 226 $6^{\mathrm{a}}$ & White, opaque and dull & Circular, raised, rough and dry, entire \\
\hline LBW 318 ${ }^{\mathrm{a}}$ & White, opaque and dull & Circular, raised, rough and dry, entire \\
\hline LBS 77 & White, opaque and dull & Circular, raised, rough and dry, entire \\
\hline LBW 261 & White, transluscent and glistening & Circular, flat, smooth, entire \\
\hline LBW 4512 & White, transluscent and glistening & Circular, flat, smooth, entire \\
\hline LBW 327 & White, transluscent and glistening & Circular, flat, smooth, entire \\
\hline LBW 434 & White, transluscent and glistening & Circular, flat, smooth, entire \\
\hline LBW 7526a & White, transluscent and glistening & Circular, flat, smooth, entire \\
\hline LBW 39 & White, transluscent and glistening & Circular, flat, smooth, entire \\
\hline LBW 7526b & White, transluscent and glistening & Circular, flat, smooth, entire \\
\hline LBW 328 & White, transluscent and glistening & Circular, flat, smooth, entire \\
\hline LBS 16 & White, transluscent and glistening & Circular, flat, smooth, entire \\
\hline LBW 625 & White, transluscent and glistening & Circular, flat, smooth, entire \\
\hline LBW 446 & White, transluscent and glistening & Circular, flat, smooth, entire \\
\hline LBW 5117 & White, transluscent and glistening & Circular, flat, smooth, entire \\
\hline LBW 313 & Yellow, transluscent and glistening & Circular, flat, smooth, entire \\
\hline LBW 317 & Yellow, transluscent and glistening & Circular, flat, smooth, entire \\
\hline
\end{tabular}

Key:

${ }^{\text {a }}$ Grew into the agar and gradually became irregular and undulate in their later stages of growth.

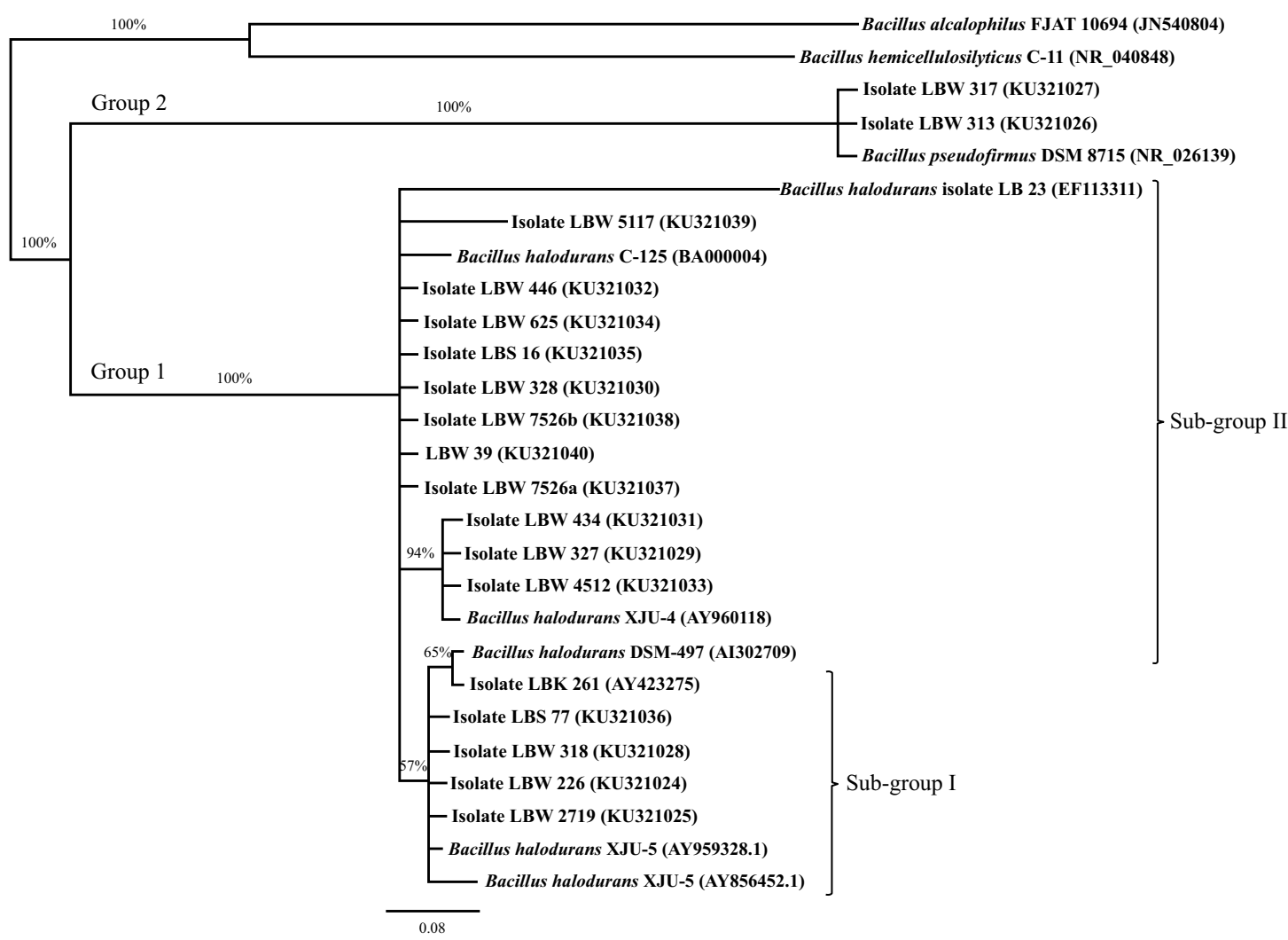

Fig. (3). An unrooted phylogenetic tree constructed from the analysis of the 16S rRNA gene sequences of the alkaliphilic soda lake Bacillus isolates and their closest relatives obtained from the NCBI database. Scale represents the average number of nucleotide substitutions per site. Bootstrap values for every 1000 trees generated are shown at the nodes. The accession numbers of the $16 \mathrm{~S}$ rRNA sequences for each isolate is shown in brackets. 
Tests based on physiological characterisation revealed that the bacilli isolates grew optimally at pH 10.5 , thus, implying that they were alkaliphiles (Table 4). These alkaliphiles were further divided into two groups: Group I (comprising 16 isolates) were able to grow in the $\mathrm{pH}$ range 7.0-11.0 while those in group 2 (comprising 2 isolates) did so in the $\mathrm{pH}$ range $>7.0-11.0$, implying that they were facultatively alkaliphilic- and obligately alkaliphilic- bacilli isolates, respectively (Table 4). Additional physiological tests revealed that group 1 isolates were further divided into two sub-groups: sub-group I (comprising 4 isolates) were able to grow up to $65{ }^{\circ} \mathrm{C}$ (optimum $37{ }^{\circ} \mathrm{C}$ ) and in the presence of up to $5 \%(\mathrm{w} / \mathrm{v}) \mathrm{NaCl}$ [optimum $0-4 \% \mathrm{NaCl}(\mathrm{w} / \mathrm{v})$ ] while sub-group II (comprising 12 isolates) grew up to $55{ }^{\circ} \mathrm{C}$ (optimum $37-45^{\circ} \mathrm{C}$ ) and in the presence of up to $10 \%(\mathrm{w} / \mathrm{v}) \mathrm{NaCl}$ [optimum $0-5 \% \mathrm{NaCl}(\mathrm{w} / \mathrm{v})$ ] (Table 4). On the other hand, group 2 (comprising 2 isolates) were able to grow up to $45{ }^{\circ} \mathrm{C}$ (optimum $37-45{ }^{\circ} \mathrm{C}$ ) and in the presence of up to $15 \%(\mathrm{w} / \mathrm{v}) \mathrm{NaCl}$ [optimum $0-5 \% \mathrm{NaCl}(\mathrm{w} / \mathrm{v})$ ]. Sub-group I isolates exhibited physiological characteristics similar to those of the facultatively alkaliphilic Bacillus sp. C-125 (re-identified as B. halodurans C-125), Bacillus sp. AH-101 (re-identified as B. halodurans) and B. halodurans M29 [29 - 31] while those in sub-group II exhibited physiological characteristics similar to those of the facultatively alkaliphilic B. halodurans DSM 497 reference/type strain [32] thus, suggesting that sub-group I isolates were stable phenotypic variants of the reference strain. This fact is also supported by the differences observed in the colony morphologies of the isolates in the two sub-groups (Table 3). On the other hand, group 2 isolates exhibited physiological and colony morphological characteristics similar to those of the obligately alkaliphilic B. pseudofirmus DSM 8715 reference strain/type strain [32]. Overall, these results suggest that the facultatively- and obligately alkaliphilic bacilli isolates in this study are tolerant to varying moderately high temperatures- and saline- conditions, which are common features of soda lakes and the hot springs there-in [1].

Table 4. Physiological characteristics of the soda lake bacterial isolates.

\begin{tabular}{|c|c|c|c|c|c|c|c|c|c|c|c|c|c|}
\hline \multirow[t]{2}{*}{ Isolate } & \multirow{2}{*}{$\begin{array}{l}\text { pH of Growth } \\
\text { (Optimum Growth) }\end{array}$} & \multicolumn{5}{|c|}{ Growth at $\left({ }^{\circ} \mathrm{C}\right)$} & \multicolumn{5}{|c|}{$\begin{array}{c}\text { Growth in Presence } \\
\text { of } \mathrm{NaCl}(\mathrm{w} / \mathrm{v})\end{array}$} & \multirow{2}{*}{\multicolumn{2}{|c|}{ Grouping }} \\
\hline & & 25 & 37 & 45 & 55 & 65 & \begin{tabular}{|l|}
0 \\
\end{tabular} & 5 & 10 & 15 & 18 & & \\
\hline LBW 2719 & $7.0-11.0(\mathrm{pH} 10.5)$ & + & ++ & + & + & $+^{\mathrm{a}}$ & ++ & $t^{\mathrm{b}}$ & - & - & - & \multirow{4}{*}{ Sub-group I } & \multirow{16}{*}{$\begin{array}{c}\text { Group 1 } \\
\text { Facultatively } \\
\text { alkaliphilic bacillus } \\
\text { isolates }\end{array}$} \\
\hline LBW 226 & $7.0-11.0(\mathrm{pH} 10.5)$ & + & ++ & + & + & $++^{\mathrm{a}}$ & ++ & $t^{\mathrm{b}}$ & - & - & - & & \\
\hline LBW 318 & $7.0-11.0(\mathrm{pH} 10.5)$ & + & ++ & + & + & $++^{\mathrm{a}}$ & ++ & $+^{\mathrm{b}}$ & - & - & - & & \\
\hline LBS 77 & $7.0-11.0(\mathrm{pH} 10.5)$ & + & ++ & + & + & $++^{\mathrm{a}}$ & ++ & $t^{\mathrm{b}}$ & - & - & - & & \\
\hline LBK 261 & $7.0-11.0(\mathrm{pH} 10.5)$ & + & ++ & ++ & + & - & ++ & ++ & + & - & - & \multirow{12}{*}{ Sub-group II } & \\
\hline LBW 4512 & $7.0-11.0(\mathrm{pH} 10.5)$ & + & ++ & ++ & + & - & ++ & ++ & + & - & - & & \\
\hline LBW 327 & $7.0-11.0(\mathrm{pH} 10.5)$ & + & ++ & ++ & + & - & ++ & ++ & + & - & - & & \\
\hline LBW 434 & $7.0-11.0(\mathrm{pH} 10.5)$ & + & ++ & ++ & + & - & ++ & ++ & + & - & - & & \\
\hline LBW 7526a & $7.0-11.0(\mathrm{pH} 10.5)$ & + & ++ & ++ & + & - & ++ & ++ & + & - & - & & \\
\hline LBW 39 & $7.0-11.0(\mathrm{pH} 10.5)$ & + & ++ & ++ & + & - & ++ & ++ & + & - & - & & \\
\hline LBW 7526b & $7.0-11.0(\mathrm{pH} 10.5)$ & + & ++ & ++ & + & - & ++ & ++ & + & - & - & & \\
\hline LBW 328 & $7.0-11.0(\mathrm{pH} 10.5)$ & + & ++ & ++ & + & - & ++ & ++ & + & - & - & & \\
\hline LBS 16 & $7.0-11.0(\mathrm{pH} 10.5)$ & + & ++ & ++ & + & - & ++ & ++ & + & - & - & & \\
\hline LBW 625 & $7.0-11.0(\mathrm{pH} 10.5)$ & + & ++ & ++ & + & - & ++ & ++ & + & - & - & & \\
\hline LBW 446 & $7.0-11.0(\mathrm{pH} 10.5)$ & + & ++ & ++ & + & - & ++ & ++ & + & - & - & & \\
\hline LBW 5117 & $7.0-11.0(\mathrm{pH} 10.5)$ & + & ++ & ++ & + & - & ++ & ++ & + & - & - & & \\
\hline LBW 313 & $>7.0-11.0(\mathrm{pH} 10.5)$ & + & ++ & ++ & - & - & ++ & ++ & + & + & - & \multirow{2}{*}{\multicolumn{2}{|c|}{$\begin{array}{c}\text { Group 1 } \\
\text { Obligately alkaliphilic bacillus isolates }\end{array}$}} \\
\hline LBW 317 & $>7.0-11.0(\mathrm{pH} 10.5)$ & + & ++ & ++ & \begin{tabular}{|l|}
- \\
\end{tabular} & - & ++ & ++ & + & + & - & & \\
\hline
\end{tabular}

All isolates grew aerobically, except for isolates LBW 313 and LBW 317 which grew both aerobically and anaerobically.

Key:

+, Growth; ++, Optimum growth; +a, Poor growth after 72 h, better growth after 96 h; +b, Weak growth; -, no growth

On the basis of molecular characterization, a phylogenetic tree was constructed using 16S rDNA sequences of the sixteen facultatively alkaliphilic- and two obligately alkaliphilic- bacilli isolates and those of their closest relatives obtained from the NCBI database. The tree divided the isolates into two distinct clusters (Fig. 3): The largest cluster (designated as group 1) comprising the sixteen facultative alkaliphiles were found to be closely related to B. halodurans DSM 497 reference strain, with sub-group I isolates showing a high sequence similarity of $99.9 \%$ and those in subgroup II showing high sequence similarities that ranged from 98.7 (isolate LBW 5117) -to- 99.8\% (isolates LBW 4512 , LBW 327, LBW 434, LBW 7526a, LBW 39, LBW 7526b, LBW 328, LBS 16, LBW 625 and LBW 446)-to- 100\% (isolate LBK 261) while the smallest cluster (designated as group 2) comprising the two obligate alkaliphiles were found to be closely related to $B$. pseudofirmus DSM 8715 reference strain with $100 \%$ sequence similarity. Both $B$ 
halodurans and B. pseudofirmus species are among the Gram positive facultative- and obligate- alkaliphiles commonly found in the Kenyan Rift valley soda lakes, respectively [33]. The limited number of alkaliphilic bacterial species in this study is attributed to the sampling methods and limited isolation conditions employed in the field and laboratory, respectively. It is interesting to note that although the facultative alkaliphilic bacterial isolates in sub-groups I and II shared high identities with $B$. halodurans DSM 497 reference strain, they exhibited significantly altered enzymatic production profiles (plate-test screening), and different colony morphological - and physiological- characteristics from one another (Tables 2,3 and 4). These differences can be attributed to phenotypic switching of sub-group II $B$. halodurans isolates to enable them adapt to new local ecological niches in the hot spring wells of Lake Bogoria where temperatures were relatively higher than in their original habitats (i.e. peripheries of hot spring wells or downstream their drainage channels) (Table 1), thus giving rise to a variant sub-population (sub-group I) of this bacterial species with different gene expressions that lead to significantly altered enzymatic production profiles and new phenotypic characteristics, as was also reported by Rodriguez [34] and Sousa et al. [35].

Alkaline proteolytic, pectinolytic and amylolytic activities of the isolates were determined quantitatively in their cell-free culture supernatants at $\mathrm{pH} 10.5$ following $48 \mathrm{~h}$ of cultivation at $37^{\circ} \mathrm{C}$ and $200 \mathrm{rpm}$ using chicken quill feather, pectin and starch as carbon or carbon/nitrogen sources in broth media, respectively. Majority of the isolates produced alkaline proteolytic enzymes when cultured in liquid media containing chicken quill feathers, hence providing an economical and readily available substrate for cultivation of the isolates. Among the positive protease producers were isolates closely associated with B. halodurans in sub-group II (0.01-0.36 U/ml) and B. pseudofirmus in group 2 $(0.38-0.40 \mathrm{U} / \mathrm{ml})$, the majority of which produced titers that were within the range of those produced by their respective reference strains (Fig. 4a). On the contrary, isolates associated with B. halodurans in sub-group I showed no detectable proteolytic activities in their culture supernatants, hence confirming that they were a variant sub-population of subgroup II isolates with an altered proteolytic production profile. The overall pattern of protease production by the isolates appear to correlate with that observed by the same isolates on solid gelatin medium during screening (Table 2). The best protease producer was isolated LBW 313 with a titer of $0.40 \mathrm{U} / \mathrm{ml}$. This enzyme can be used to catalyze the hydrolysis or synthesis of peptide bonds at alkaline $\mathrm{pH}$ and can therefore, find applications in a) detergent industry - as an additive to detergents, for hydrolysis of proten-based stains in laundry or dishes during washing b) leather industry - to dehair hide and produce high quality leather c) waste management - to solubilize proteins in protein-containing food wastes in order to recover liquid concentrates or dry solids of nutritional values for incorporation in fish or livestock feeds and d) chemical industry - to synthesize fine speciality chemicals.

All isolates closely related to $B$. halodurans were able to produce the alkaline pectinolytic enzyme PGase $(0.05-0.46$ $\mathrm{U} / \mathrm{ml}$ ) while those closely related to $B$. pseudofirmus showed no detectable activity of this enzyme (Fig. 4b). A similar pattern of PGase production was observed with their respective reference strains. Like on solid pectin medium, these pectinolytic titers were relatively higher for sub-group I isolates $(0.12-0.56 \mathrm{U} / \mathrm{ml})$ compared to those of sub-group II (0.05-0.10 U/ml), despite the fact that isolates in both sub-groups were B. halodurans (Fig. 4b). This altered pectinolytic production profile further confirms that sub-group I isolates were indeed a variant sub--population of subgroup II $B$. halodurans isolates. PecL is another pectinolytic enzyme that was only detected in the cell-free culture supernatants of sub-group II isolates (Fig. 4b). The absence of this enzyme in the cell-free culture supernatants of subgroup I isolates also demonstrates that sub-group I isolates were sub-population variants of sub-group II B. halodurans isolates. Isolate LBK 261 was the best producer of both PGase and PecL $(0.12$ and $0.1 \mathrm{U} / \mathrm{ml}$, respectively) while isolate LBW 318 was the best producer of PGase $(0.46 \mathrm{U} / \mathrm{ml})$. PGases and PecLs cleave $\alpha-(1 \rightarrow 4)$ glycosidic linkages in polygalacturonic acid polymers via hydrolytic and trans-elimination reactions, respectively. Thus, the presence of both alkaline enzymes in the cell-free culture supernatants of sub-group II isolates is interesting, since this cocktail of enzymes can be very effective in degrading the polymer, and for this reason they can find applications in the a) pulp and paper industry - to effectively depolymerize polygalacturonic acid polymers in pulps for enhanced bleachability and consequent production of good quality paper with high opacity and good printability b) textile industry - to degum, ret or scour natural plant fibers for textile manufacture.

All isolates closely associated with B. halodurans and B. pseudofirmus produced a cocktail of alkaline amylolytic enzymes, with the former isolates producing higher titers of amylases and pullulanases compared to those produced by the latter isolates and the reference strains while CGTase titers remained low for all isolates (Fig. 4c). The low levels of CGTases in the culture supernatants of the isolates can be attributed to unoptimized bioconversion conditions (e.g. temperature, $\mathrm{pH}$, cultivation time as well as product inhibition) during cell culture. Interestingly, these amylolytic titers did not correlate with those produced by the same isolates on solid alkaline starch medium (Table 2). This difference 
can be attributed to differences in the a) uptake of nutrients by the isolates in the two types of media and/or b) activity detection rule e.g. in the solid medium the disappearance of the substrate is measured while in liquid medium the appearance of the product is measured, as was also reported by Castro et al. [36]. The best producer of the alkaline amylolytic enzymes was isolated LBW 5117 (0.32, 0.68 and $0.02 \mathrm{U} / \mathrm{ml}$ amylases, pullulanases and CGTases, respectively). Amylases hydrolyze internal $\alpha-1,4$ linkages in starch while pullulanases (debranching enzymes) hydrolyze $\alpha-1,6$ linkages in starch, amylopectin and pullulan. Thus, the finding of both alkaline amylases and pullulanases in the culture supernatants of the isolates is interesting because this combination of enzymes can be very effective in removing both starch-based sizes (desizing) from cotton yarn during the modern production of textiles and starch-based stains from laundry and dishes. CGTases on the other hand, convert starch into cyclic cyclodextrins whose hydrophobic cavities can form complexes with organic foods and, pharmaceutical- and cosmetic- products to improve their solubility and stability properties.

(a)

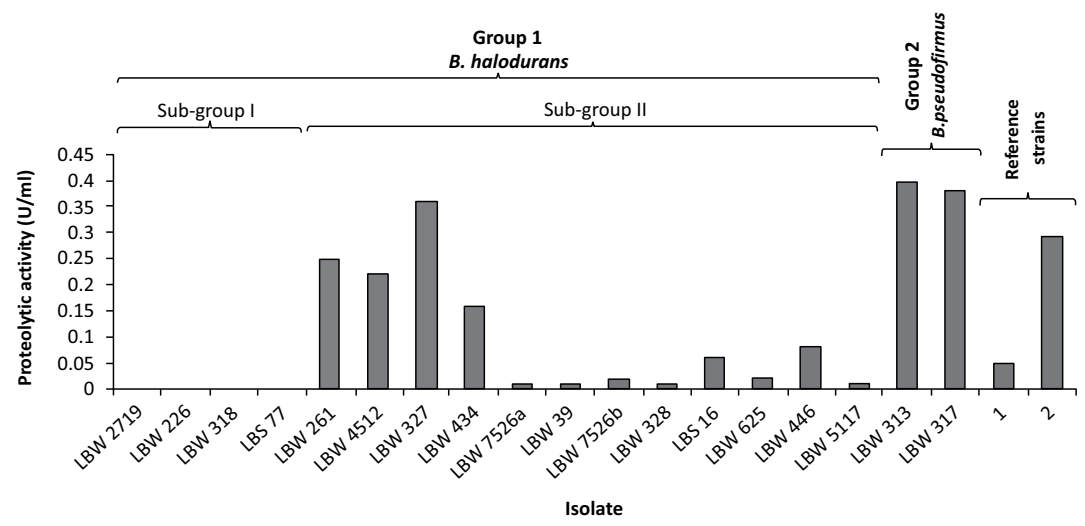

(b)

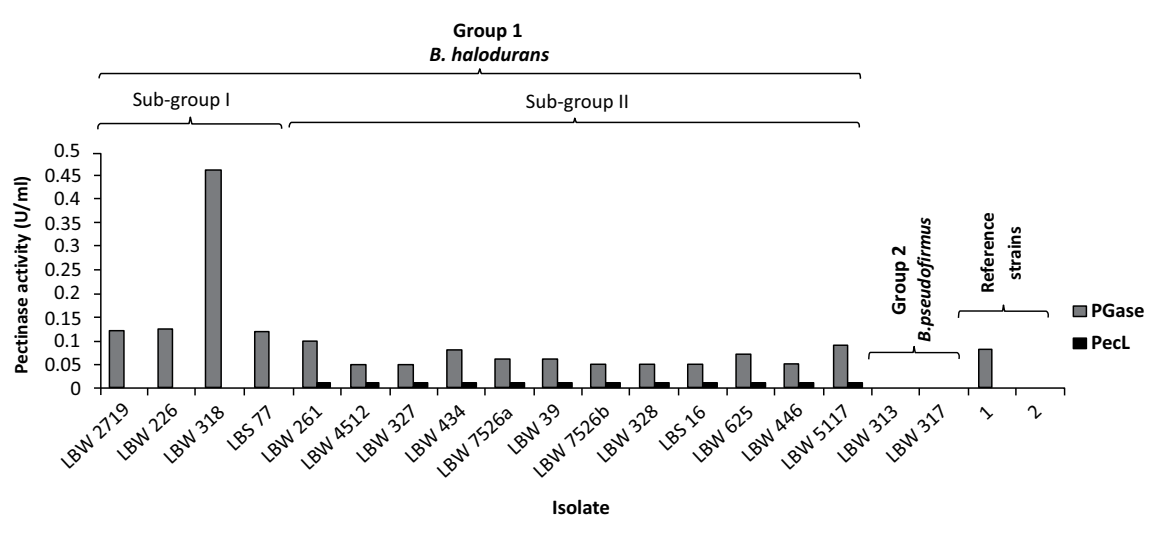

(c)

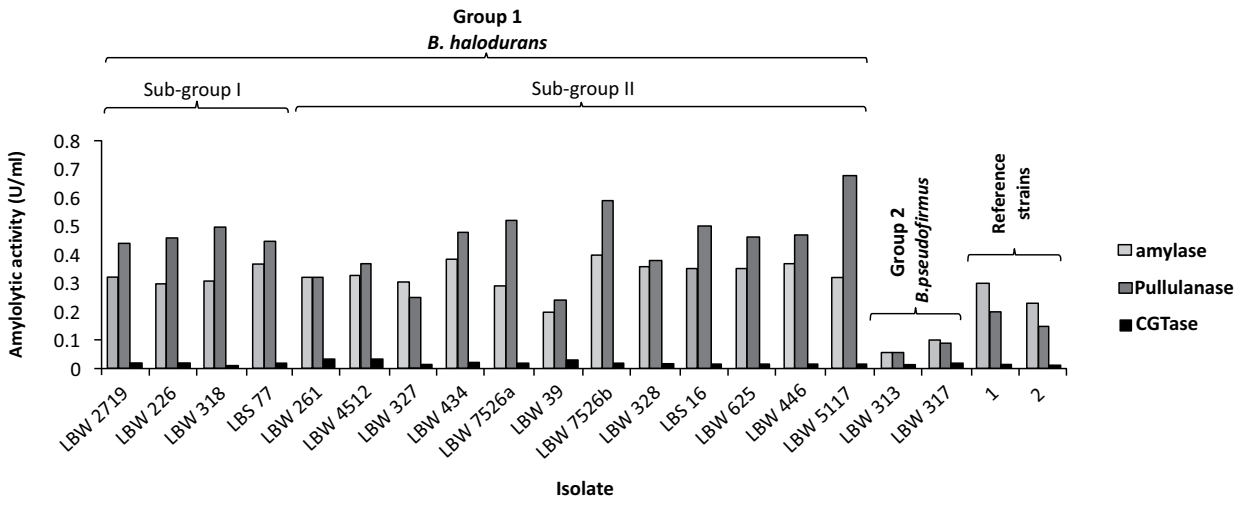

Fig. (4). Proteolytic (a), pectinolytic (b) and amylolytic (c) activities of the alkaliphilic soda lake bacterial isolates and the reference strains $(1=$ B. halodurans DSM 497 and $2=$ B. pseudofirmus DSM 8715). 


\section{CONCLUSION}

Twelve facultatively alkaliphilic $B$. halodurans, four phenotypic sub-population variants of this bacterial species and two obligately alkaliphilic B. pseudofirmus Lake Bogoria isolates are attractive biotechnological sources of alkaline amylolytic enzymes, with the majority also being sources of alkaline pectinolytic and proteolytic enzymes - all of which can find applications in various industrial technologies for production of high quality products in a safe way. Our current work is targeted at the textile industry where we are evaluating the use of alkaline amylolytic enzymes from $B$. halodurans isolate LBW 5117 in desizing cotton yarn in preparation for its scouring (bioscouring) with PGase from $B$. halodurans isolate LBW 318 in order to improve its performance in further finishing steps. We also intend to evaluate the catalase-positive $B$. halodurans isolate LBK 261 as an immobilized whole cell biocatalyst to degrade hydrogen peroxide in simulated textile bleach wastewaters.

\section{AUTHORS' CONTRIBUTION}

Oluoch KR, Okanya PW, Hatti-Kaul R, Mattiasson B and Mulaa FJ collected the samples from Lake Bogoria; Oluoch KR and Okanya PW isolated the bacteria; Oluoch KR and Mulaa FJ designed the study; Oluoch KR performed the experiments, analyzed the data and wrote the manuscript whose final version was approved by Mulaa FJ.

\section{ETHICS APPROVAL AND CONSENT TO PARTICIPATE}

Not applicable.

\section{HUMAN AND ANIMAL RIGHTS}

No Animals/Humans were used for studies of this research.

\section{CONSENT FOR PUBLICATION}

Not applicable.

\section{CONFLICT OF INTEREST}

The authors declare no conflict of interest, financial or otherwise.

\section{ACKNOWLEDGEMENTS}

The authors would like to thank the Department of Biochemistry, University of Nairobi, for providing the laboratory space used for this study; the authors would like to express their sincere gratitude to Prof. Wallace D. Bulimo, Dr. Edward K. Muge, Mr. Nelson Khan and Ms Irene K Kateve of the University of Nairobi, for their useful suggestions in the study.

\section{REFERENCES}

[1] Grant WD, Tindall BJ. The alkaline saline environment.Microbes in extreme environments. London: Academic Press 1986; pp. 25-54.

[2] Grant WD, Horikoshi K. Alkaliphiles: Ecology and biotechnological applications.IEMS Microbiology Letters. 1992; 75: pp. $255-69$. [http://dx.doi.org/10.1007/978-94-011-2274-0_5]

[3] Horikoshi K. Alkaliphiles: Some applications of their products for biotechnology. Microbiol Mol Biol Rev 1999; 63(4): 735-50. [PMID: 10585964]

[4] Grant WD, Jones BE. Alkaline environments.Encyclopedia of microbiology. 2nd ed. New York: Academic Press 2000; Vol. 1: pp. 126-33.

[5] Fujinami S, Fujisawa M. Industrial applications of alkaliphiles and their enzymes--past, present and future. Environ Technol 2010; 31(8-9): 845-56. [http://dx.doi.org/10.1080/09593331003762807] [PMID: 20662376]

[6] Sarethy IP, Saxena Y, Kapoor A, et al. Alkaliphilic bacteria: Applications in industrial biotechnology. J Ind Microbiol Biotechnol 2011; 38(7): 769-90. [http://dx.doi.org/10.1007/s10295-011-0968-x] [PMID: 21479938]

[7] Sundarram A, Murthy TPK. $\alpha$-Amylase production and applications: A review. J Appl Environ Microbiol 2014; 2 : 166-75.

[8] Stårnes RL. Industrial potential of cyclodextrin glycosyl transferases. Cereal Foods World 1990; 35: 1094-9.

[9] Ellaiah P, Srinivasulu B, Adinarayana K. A review on microbial alkaline proteases. J Sci Ind Res (India) 2002; 61: 690-704.

[10] Kohli P, Gupta R. Alkaline pectinases: A review. Biocatal Agric Biotechnol 2015; 4: 279-85. [http://dx.doi.org/10.1016/j.bcab.2015.07.001] 
[11] Okanya SWP. Screening for anti-plasmodium activity using extracts from extremophiles found in Lake Bogoria, Kenya. Dissertation, University of Nairobi 2006; pp. 23-25.

[12] Juwon AD, Emanuel OF. Screening of fungal isolates from Nigerian tar sand and deposit in Ondo state for novel biocatalysts. J Biol Sci 2012; 12: 57-61.

[http://dx.doi.org/10.3923/jbs.2012.57.61]

[13] Soares MMCN, Da Silva R, Gomes E. Screening of bacterial strains for pectinolytic activity: Characterization of the polygalacturonase produced by Bacillus sp. Rev Microbiol 1999; 30: 299-303. [http://dx.doi.org/10.1590/S0001-37141999000400002]

[14] Kelly CT, Fogarty WM. Production and properties of polygalacturonate lyase by an alkalophilic microorganism Bacillus sp. RK9. Can J Microbiol 1978; 24(10): 1164-72.

[http://dx.doi.org/10.1139/m78-190] [PMID: 31973]

[15] Horikoshi K. Production of alkaline enzymes by alkalophilic microorganisms Part II. Alkaline amylase produced by Bacillus No. A-40-2. Agric Biol Chem 1971; 35: 1783-91. [http://dx.doi.org/10.1271/bbb1961.35.1783]

[16] Dhawale MR, Wilson JJ, Khachatourians GG, Ingledew WM. Improved method for detection of starch hydrolysis. Appl Environ Microbiol 1982; 44(3): 747-50. [PMID: 16346102]

[17] Hitha PK, Girija D. Isolation and screening of native microbial isolates for pectinase activity. Int J Sci Res (Ahmedabad) 2014 ; 3: 632-4.

[18] Gerhardt P, Murray RGE, Wood WA, Krieg NR. Methods for general and molecular bacteriology. Washington, DC: American Society for Microbiology 1994.

[19] Gregersen T. Rapid method for distinction of Gram-negative bacteria from Gram-positive bacteria. Eur J Appl Microbiol Biotechnol 1978; 5: $123-7$.

[http://dx.doi.org/10.1007/BF00498806]

[20] Martins RF, Davids W, Abu Al-Soud W, Levander F, Rådström P, Hatti-Kaul R. Starch-hydrolyzing bacteria from Ethiopian soda lakes. Extremophiles 2001; 5(2): 135-44. [http://dx.doi.org/10.1007/s007920100183] [PMID: 11354457]

[21] Johnson JL. Similarity analysis of DNAs.Methods for general and molecular bacteriology. Washington, DC: American Society for Microbiology 1994; pp. 655-81.

[22] Weisburg WG, Barns SM, Pelletier DA, Lane DJ. 16S ribosomal DNA amplification for phylogenetic study. J Bacteriol 1991; 173(2): 697-703. [http://dx.doi.org/10.1128/jb.173.2.697-703.1991] [PMID: 1987160]

[23] Edgar RC. MUSCLE: Multiple sequence alignment with high accuracy and high throughput. Nucleic Acids Res 2004; $32(5)$ : 1792-7. [http://dx.doi.org/10.1093/nar/gkh340] [PMID: 15034147]

[24] Huelsenbeck JP, Larget B, Miller RE, Ronquist F. Potential applications and pitfalls of Bayesian inference of phylogeny. Syst Biol 2002; 51(5): 673-88.

[http://dx.doi.org/10.1080/10635150290102366] [PMID: 12396583]

[25] Bakhtiar S, Andersson M, Gessesse A, Mattiasson B, Hatti-Kaul R. Stability characteristics of a calcium- independent alkaline protease from Nesterenkonia sp. Enzyme Microb Technol 2002; 32: 525-31.

[http://dx.doi.org/10.1016/S0141-0229(02)00336-8]

[26] Wang G, Michailides TJ, Bostock RM. Improved detection of polygalacturonase activity due to Mucor piriformis with a modified dinitrosalicylic acid reagent. Phytopathology 1997; 87(2): 161-3. [http://dx.doi.org/10.1094/PHYTO.1997.87.2.161] [PMID: 18945136]

[27] Soriano M, Diaz P, Pastor FIJ. Pectate lyase C from Bacillus subtilis: A novel endo-cleaving enzyme with activity on highly methylated pectin. Microbiology 2006; 152(Pt 3): 617-25.

[http://dx.doi.org/10.1099/mic.0.28562-0] [PMID: 16514142]

[28] Ash C, Farrow JAE, Wallbanks S, Collins MD. Phylogenetic heterogeneity of the genus Bacillus as revealed by comparative analysis of small-subunit-ribosomal RNA sequences. Lett Appl Microbiol 1991; 13: 202-6.

[http://dx.doi.org/10.1111/j.1472-765X.1991.tb00608.x]

[29] Takami H, Horikoshi K. Reidentification of facultatively alkaliphilic Bacillus sp. C-125 to Bacillus halodurans. Biosci Biotechnol Biochem 1999; 63(5): 943-5. [http://dx.doi.org/10.1271/bbb.63.943] [PMID: 27385575]

[30] Takami H, Nogi Y, Horikoshi K. Reidentification of the keratinase-producing facultatively alkaliphilic Bacillus sp. AH-101 as Bacillus halodurans. Extremophiles 1999; 3(4): 293-6. [http://dx.doi.org/10.1007/s007920050130] [PMID: 10591021]

[31] Mei Y, Chen Y, Zhai R, Liu Y. Cloning, purification and biochemical properties of a thermostable pectinase from Bacillus halodurans M29. J Mol Catal, B Enzym 2013; 94: 77-83. [http://dx.doi.org/10.1016/j.molcatb.2013.05.004] 
[32] Nielsen P, Fritz D, Priest FG. Phenetic diversity of alkaliphilic Bacillus strains: Proposal for nine new species. Microbiol 1995 ; 141 : $1745-61$. [http://dx.doi.org/10.1099/13500872-141-7-1745]

[33] Duckworth AW, Grant WD, Jones BE, Steenbergen R. Phylogenetic of soda lake alkaliphiles. FEMS Microbiol Ecol 1996; 19: 181-91. [http://dx.doi.org/10.1111/j.1574-6941.1996.tb00211.x]

[34] Rodriguez H. Colony switching in an alpha-amylase-producing strain of Bacillus subtilis. J Ind Microbiol 1995; 15: 112-5. [http://dx.doi.org/10.1007/BF01569809]

[35] Sousa AM, Machado I, Pereira MO. Phenotypic switching: An opportunity to bacteria thrive.Science against microbial pathogens: Communicating current research and technological advances. 2011; pp. 252-62.

[36] Castro GR, Ferrero MA, Méndez BS, Sineriz F. Screening and selection of bacteria with high amylolytic activity. Acta Biotechnol 1993; 13: 197-201.

[http://dx.doi.org/10.1002/abio.370130220]

\section{(C) 2018 Oluoch et al.}

This is an open access article distributed under the terms of the Creative Commons Attribution 4.0 International Public License (CC-BY 4.0), a copy of which is available at: (https://creativecommons.org/licenses/by/4.0/legalcode). This license permits unrestricted use, distribution, and reproduction in any medium, provided the original author and source are credited. 